\title{
Immigrants' Characteristics and the Croatian Labour Market: an Explorative Study
}

DOI: 10.11567/met.31.1.2 UDK: 314.742:331.5](497.5)"1998/2014" 331.556.4(497.5)"1998/2014"

Pregledni rad Primljeno: 30. 09. 2014. Prihvaćeno: 23. 04. 2015.

Valerija Botrić

Ekonomski institut, Zagreb

vbotric@eizg.hr

\begin{abstract}
SUMMARY
Labour market outcomes of immigrant populations are interesting from different aspects, both as an academic question but also in terms of policy design. The potential research questions include whether immigrants face adverse prospects on local labour markets, what segment of the market do they fill and whether they contribute positively to the overall economic development of the host country. By relying mostly on the Labour Force Survey for the 1998-2012 period, this paper aims at providing additional insight into the labour market position of immigrants in Croatia. Several indicators of the immigrant population have been compared to those of the domestic population - age, educational attainment, occupational structure and unemployment. The data indicate that immigrants in Croatia do not belong to young and highly-skilled population subgroups - which are characteristics frequently associated with out-migration profiles - but are instead similar to an extent to the host country population.
\end{abstract}

KEY WORDS: immigrants, Croatia, labour market, Labour Force Survey

\section{INTRODUCTION}

Croatia has demographic features similar to other European Union (EU) countries, which have important consequences for respective labour markets (Nestić et al., 2013). The notion that demographic factors might influence the economies' development has been widely discussed in the European Union - fiscal repercussions of the aging population, health system considerations or appropriate age for retirement are just a few frequently debated topics. One of the remedies sought to alleviate the unfavourable demographic structure is to create positive worker immigration flows. This is not a novelty of the recent EU process, since many countries (Germany, The Netherlands, Switzerland, etc.) already required an additional work 
force and designed the guest-worker programmes in the aftermath of the Second World War. Although Croatian citizens participated in these historic episodes as migrant workers, the demographic aging in Croatia might influence the need for attracting foreign workers to Croatia and consideration of the issue in the broader perspective.

Public debates in Croatia on the subject are mostly related to specific economic activities, when employers are not able to fill the demand on the local labour market. In addition to employers' requests for more active immigration policy, in particular in certain sectors, academics and professionals have also acknowledged the need to address this issue in more detail. For example, Crnković-Pozaić (2008) stated that it is highly likely that Croatia will require more foreign workers in the long run. She also argued that the structure of foreign workers will have to change, from traditional occupations such as ship-building and construction that demand low-skilled workers to more highly-skilled workers.

At the same time as being a society with pronounced demographic aging (Nejašmić, 2012), the Croatian economy is land-marked by high unemployment, which actually spurs emigration from Croatia. Indeed, the relevant Central Bureau of Statistics (CBS) data on annual migration flows reveals that since 2009 the Croatia has been experiencing a negative net migration rate, while previously net migration was positive. This calls for consideration of whether the question of attracting foreign workers is relevant in the short term. The future competitive position of the economy certainly depends on the available labour resources. Long-term unemployment spells are contributing to the skills deterioration of the domestic labour force, while adverse demographic structure additionally burdens the supply side of the labour market. The solution for improving the competitiveness of the economy might be to fill the labour market gaps with foreign workers. In this situation, the relevant policy question could well be how to attract foreign workers to Croatia, and what prospects they could expect.

The underlying theory on the relative position of the immigrant population on the local labour market is associated with intergroup conflict theory (Coleman and Rowthorn, 2004). According to these considerations, immigrants are more likely to be considered as a threat to the domestic population and have poor prospects on the local labour market. In EU countries, studies frequently establish lower performance of migrants on the labour market in comparison to the domestic population (Büchel and Frick, 2005; Bernardi, Garrido and Miyar, 2011; Fullin and Reyneri, 2011; Kogan, 2011). The studies usually find that various socioeconomic determinants are im- 
portant explanations for the difference in labour market outcomes (such as age, gender, education, marital status, language skills). Whether this is also the case for the Croatian labour market is not frequently analysed in the literature.

The main goal of this paper is to analyse the position of immigrants on the Croatian labour market over the longer time period in order to be able to discuss potential trends formation. To achieve this goal, the 1998-2012 period has been used, which entails phases of economic prosperity and economic downturn. Although this period is relatively short when migrations are concerned, it might be long enough to reveal the dynamics related to the labour market. The main focus is thus the work-related aspect of migration to Croatia. The Labour Force Survey (LFS) is the main dataset used to analyse national labour market indicators, yet relatively rarely used in Croatia to analyse migrant workers. To the best knowledge of the author, this is the first attempt to fill this gap in the Croatian literature.

The structure of the paper is the following. The next section discusses the data used and defines indicators in the empirical section. Section 3 presents origin of immigrants in Croatia and contains comparative analysis of age structure of the immigrant versus the domestic population. Section 4 discusses differences in educational attainment. Section 5 discusses occupational differences, while section 6 presents differences in unemployment indicators for the domestic versus the immigrant population. The last section summarizes the main conclusions.

\section{METHODOLOGY AND DATA SOURCES}

The main focus of the paper is to determine the position of immigrant workers in Croatia by providing the set of indicators in comparison to domestic workers. This will enable us to discuss the characteristics of workers attracted by the Croatian labour market.

The main data source for the analysis in this paper is the Labour Force Survey ${ }^{1}$ (LFS), due to the fact that it has been a relatively under-utilized

Basic information on the methodology of the LFS is published within every first release of the data on the CBS Internet page www.dzs.hr. Therefore, here we only briefly present the key information relevant for the data presented in the analysis that follows. In Croatia, LFS was carried out for the first time in November 1996 as an annual survey. It was carried out in the same manner in June 1997. The Survey has been carried out continuously since 1998, meaning that a part of the total sampled households is interviewed every month. Interviewers visit each household and conduct an interview lasting approximately 20 minutes. "Persons in employment" are those who were engaged in any work for payment in cash or kind during the reference week. The Survey covers all persons who had worked for at least one hour in the reference period, irrespective of their formal status 
source for the analysis of migration in the case of Croatia. ${ }^{2}$ The Survey has been regularly conducted by the CBS since 1996 and, according to the methodology sample, is designed in order to produce estimates of labour market indicators on the national level. However, to the best knowledge of the author, this relatively rich data source has not been previously used for the analysis ${ }^{3}$ performed in this paper. The analysed period covers 1998-2012. The first two years have not been included in the analysis, due to the fact that the Survey started as a pilot project. Throughout the analysed period, some methodological changes in the Survey occurred. One of the most important was the introduction of the panel component in 2007. In order to avoid double counting of respondents' answers, the original sample has been downsized since 2007 by keeping only the responses of the first-time appearance of the specific wave (see, for example Botrić, 2012; Drinkwater and Robinson, 2011).

The changes in the methodology - such as introduction of or rephrasing specific questions - influences the possibility of designing a comparable time series for the analysis of the immigrants' position on the Croatian labour market. Additionally, it can be assumed that the quality of the data source itself increases with time, so the more recent LFS can be associated with more support from the data provider. ${ }^{4}$ In order to try to circumvent this issue, careful description of the data used in this paper is provided.

The sample was restricted to the respondents who had resided in the sampled household during the last 12 months, thus excluding the out-migration (within Croatia or international) potential for the analysis. Before 2006, the question related to the identification of immigrants in the LFS was limited to persons with foreign citizenship. ${ }^{5}$ This extremely narrow defini-

or means of payment. "Unemployed persons" are those who meet the following three criteria: a) did not work for payment in cash or kind in the reference period; $b$ ) were actively seeking work during four weeks prior to the Survey, and c) were currently available for work within the next two weeks. Those who have found a job to start in the future are also included. "Inactive population" in the Survey consists of persons under the age of 15 as well as those of working age who are neither employed nor unemployed.

2 However, some important aspects cannot be analysed with the Labour Force Survey data. In these cases, more frequently used data sources have been consulted, presented and discussed.

3 The CBS has provided depersonalized individual data from the Survey for the 1998-2012 period, and all the aggregations and additional analyses of the Survey were performed by the author.

4 For example, if there are some data issues, the likelihood that they could be resolved decreases with the number of passing years since the data collection.

5 These are persons who have declared that they have foreign citizenship, although they reside in Croatia and most likely have valid residence permits. However, we have to keep in 
tion does not enable analysis of an important segment of the immigrant population - persons who were born in the former Yugoslavian countries, but who have obtained citizenship after the break-up. Since 2006, the LFS questionnaire has been extended in this segment, and we are able to track the persons according to their country of birth. So, in addition to citizenship, we also defined immigrants as those who were foreign-born. This latter definition is much broader and is also used in the analysis of labour market impacts of immigration in other countries (Markaki, 2014). We argue that broader definition fits the purpose of analysing labour market outcomes in Croatia comparatively even more than documented in other countries. Specifically, if a person is entitled to Croatian citizenship, then he or she would not have been counted as an immigrant according to the narrow definition, even if that person had moved to Croatia only recently. However, that person might still face adverse conditions on the Croatian labour market due to - for example - education system differences and the length of recognition of qualifications processes - i.e., might face similar difficulties as other immigrants. Since the aim is to investigate whether there are differences between the immigrant and domestic population, broader definition seems more appropriate.

The difference between the two definitions of immigrant population is striking. If we examine the average share of immigrants during the overlapping period when two questions are asked simultaneously in the LFS (i.e. 2006-2012), then we have only 0.17 percent of the sample referring to foreign citizens and 11.05 percent of the sample referring to foreign-born persons (including those with foreign citizenship). Although the aim of the analysis in this paper is to provide the longer perspective of the labour market situation of the immigrant population in Croatia, the relatively low shares of foreign citizens in the sample limits the interpretability of the analysis during the 1998-2006 period. In order to try to circumvent this problem, we restrict the presentation of the data as period averages only. ${ }^{6}$ The main idea was that by pooling across years we would be able to enlarge the sample enough to be able to discuss at least the structural differences between the foreign citizens and the domestic population.

The main aim of the LFS is to analyse the labour market situation on the national level. In order to improve its usage for migration analysis, some

mind that LFS data is based on the responses of the individuals who might not be aware of specificities related to the legal status of their stay in Croatia. Consequently, we might expect differences between administrative sources (such as those related to the Ministry of the Interior registers) and the results obtained from the Survey.

6 Annual data can be obtained from the author upon request. 
countries have extended their Surveys in particular years to capture this segment. On the EU level, Eurostat introduced the LFS ad hoc module on the labour market situation of migrant workers in 2008. Since the data analysed in this paper is not destined for migration analysis, we refrain from expanding the data to the national level due to the questionable suitability of the weights for our purpose, and present only the sample-level results. In the same manner, no corrections for not answering specific questions were made. Since we are pooling the answers across the years without these corrections, the analysed indicators might have undesirable properties - for example, the shares do not add up to 1 (or 100). ${ }^{7}$ However, we argue that, due to sample properties, an attempt to alleviate these issues by standard statistical procedures might further distort the data.

By relying on LFS, the analysis is limited to the existing questionnaire and indicators that could be analysed based on them. One of the important questions related to the demographic aging of the Croatian population is whether the immigrant population is younger, thus filling the gaps in the demographic pyramid. We calculate the age of the person at the year of the Survey, based on the information on the year of the birth.

In the immigration analysis, it is interesting to analyse the existence of migration hubs. Patterns of migration flows according to the type of settlement have been widely discussed in the literature - Huff (1976), for example, presents the redistribution according to central place hierarchy, which has desirable economic properties (such as demand for labour). More recent contributions explore the migration patterns across the lifetime of individuals which seem to indicate downward movements in the urban hierarchy (Plane, Henrie and Perry, 2005). Due to the nature of the sample, which is aimed to be representative at the national and not regional level, we abstain from making conclusions on specific geographical areas, but consider the type of areas mostly chosen by the migrant population instead. Thus we assume that immigrants in Croatia tend to choose urban settlements, according to the traditional models, although we cannot detect the type of settlement they have previously lived in. The LFS distinguishes four types

Every survey has cases when respondents chose not to answer specific questions, i.e. the cases of "item" non-response. The reason might be that they are not aware of the correct answer or they simply decide not to reveal it. When the survey has many questions, such as the LFS, the probability of non-responding is higher. Although "unit" non-response is usually perceived as a major cause for concern that statistical offices try to correct for before publishing their data, "item" non-response is also important for some studies (Sandström, 2002). Since we do not make such corrections, the issue becomes evident in the ratios - the number of respondents in the nominator is not equal to the number of respondents in the denominator. 
of settlements. For the purposes of analyses, we determined that a person lives in an urban settlement if it has been classified by LFS as urban or semiurban.

The skills of the immigrants are crucial for the labour market. Saleheen and Shadforth (2006) argue that if immigrants are predominately lowskilled, then they have the potential to lower their host country's productivity growth in the short run and the productivity level in the long run. They also argue that this could influence the nominal wage growth and in the case the migrant workers fill in the existing skills gaps, and help to lower the natural unemployment rate without increasing inflation. If immigrant skills are complementary to those of the domestic population, according to these authors it could even increase the participation of the previously inactive on the labour market and increase potential output.

Education is a human capital variable, which is highly important in the labour market context. It is important to distinguish whether the immigrants to Croatia are similar to the domestic population in terms of educational attainment. In order to analyse this aspect, categories of level of education in LFS were grouped in three segments. As primary and lower secondary education, categories "No school”, "1-3 basic school grades", " $4-7$ basic school grades" and "Basic school" are considered. As upper secondary education, categories "School for skilled and highly skilled workers", "Vocational secondary schools" and "Grammar school" are included. As tertiary education, categories from "Non-university college" to "Doctorate" are considered. The traditional work-related migrations to Croatia were in low-skills labour demand sectors, such as construction or ship-building. ${ }^{8}$ Indeed, the annual quota system the Government introduced in 2004 in Narodne novine - Official Gazette of the Republic of Croatia reveals that precisely those activities were listed as activities with a high demand for workers. The quota system also reveals the sharp decline in labour demand for foreign workers, probably as a consequence of the economic crisis. For example, in a

As an illustration, we have analysed the structure of employed foreign-born persons in two specified NACE activities according to their education attainment in 2006 and 2012 (in order to have 2 reference points prior and during the economic crisis). The sample data shows that the share of employed foreign-born persons with upper-secondary education was dominant in both occupations in 2006 - approximately 90 percent in ship-building and 65 percent in construction. The sample was able to cover a larger number of persons employed in construction, than in ship-building. Consequently, construction activity also employed approximately 6 percent of foreign-born persons with tertiary education. In 2012, all employed foreign-born persons in ship-building had upper-secondary education, and the structure of educational attainment in construction also indicated the dominant share of upper-secondary (85 percent). 
pre-crisis 2008, when the construction boom was still evident in Croatia, the quota system foresaw 10242 workers, out of which 5330 in construction activity. For 2014, the overall quota was set at 2256 with not a single worker expected in construction. ${ }^{9}$

In addition to education differences, we also want to address the issue of occupational differences of those who do find a job in Croatia. Occupations data are aggregated according to the main categories of International Standard Classification of Occupations (ISCO classification).

Another question that we wanted to explore was the issue of unemployment. Since Croatia is suffering from high unemployment rates, the main question is whether immigrants in Croatia are in a more or less more favourable position on the local labour market. To that end, we explore the unemployment rates of the immigrant population and compare them to the domestic population.

Due to data limitations, the results are presented for the two separate time periods. The first one refers to 1998-2006, when only information on foreign citizenship was available for the analysis. The second period overlaps the first one, and covers the years 2006-2012. Before presenting the results, it is interesting to note the differences in the two immigration population concepts analysed in this paper, by inspecting their differences in the overlapping year. For example, foreign citizens comprised only 0.28 percent of the sample, while foreign-born amounted to 12.15 percent in year 2006. The average net wage of foreign citizens was 8.3 percent higher than the average wage of the domestic population, while the average net wage of foreign-born persons was 0.5 percent lower. These data imply that there are large differences between two categories of immigrants - foreign citizens and those not born in Croatia. Since wider definition of immigrants (i.e. persons not born in Croatia) would be more desirable for analysis, it would be tempting to extrapolate the conclusions for the whole period, based on the indicators for foreign citizens. The huge differences in the overlapping year - 2006 - warn against such conclusions.

For a comparative overview of quota system responses to the global economic crisis in Croatia and other Western Balkan countries, please consult the recent report edited by Dedovic (2015). 


\section{COUNTRY OF ORIGIN AND AGE STRUCTURE OF IMMIGRANTS TO CROATIA}

Croatian CBS publishes regularly data on the age structure of immigrants to and emigrants from Croatia with annual frequency from 2002 (Migracija stanovništva Republike Hrvatske). In addition to the census, these data provide the most comprehensive introspection of the most recent migration flows in Croatia. So, to illustrate the characteristics of the sample used in this paper, we compare the basic age structure according to the different data sources. It has to be emphasized, though, that the annual CBS data captures migration flows, while the LFS sample depicts sample data on migration stock.

Figure 1. Age structure of migrants of LFS, average 2006-2012

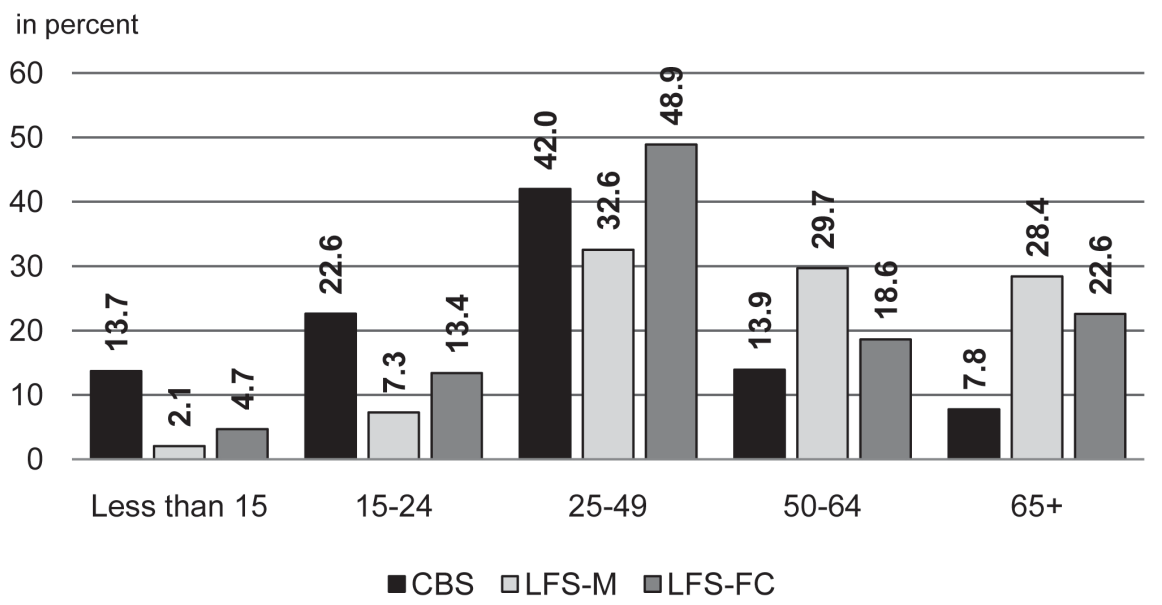

Note: CBS refers to Central Bureau of Statistics migration data, LFS-M refers to LFS data on foreign-born persons, and LFS-FC refers to LFS data on persons with foreign citizenship.

Source: Central Bureau of Statistics for original data, author's representation.

Figure 1 shows that during the analysed period, predominately younger population subgroups came to Croatia. This is consistent with the evidence that younger persons are more likely to make migration decisions in normal circumstances. The stock data, on the other hand, reveal a relatively large share of older population subgroups, both for foreign-born persons and, to a lesser extent, foreign citizens. One of the explanations for this discrepancy 
might be related to the sample structure of the LFS, ${ }^{10}$ which is more likely to capture persons that are already in Croatia for a longer period of time, while flow data is also capturing more mobile segments of migration. From a labour market perspective, it could be argued that both longer term and shorter term migrations are important. Long-term migrations are important since they create long-lasting pressure on the labour market in terms of increased supply. Short-term migrations might affect the labour market only in specific seasons. For example, in specific seasonal activities (hotels and restaurants on the Croatian coast), the employment of migrant workers only during the high-season seems an important phenomena, which is not likely to be captured by the LFS data.

To determine the impact of immigrants on the Croatian demographic structure, we proceed with their comparison with the domestic population. It has to be emphasized that LFS data is not the most relevant source for analysing effects on demographic structure. However, demographic characteristics of immigrants might be related to their employability, which redeems the use of this data source for the purpose of present analysis

Table 1. Age and urban population structure in percentage, 1998-2012

\begin{tabular}{lcc|ccc}
\hline & \multicolumn{2}{c|}{ Average 1998-2006 } & \multicolumn{3}{c}{ Average 2006-2012 } \\
\cline { 2 - 6 } & $\begin{array}{c}\text { Foreign } \\
\text { citizens }\end{array}$ & $\begin{array}{c}\text { Croatian } \\
\text { citizens }\end{array}$ & $\begin{array}{c}\text { Foreign- } \\
\text { born }\end{array}$ & Domestic & $\begin{array}{c}\text { Foreign } \\
\text { citizens }\end{array}$ \\
\hline Less than 15 & 11.23 & 15.05 & 2.07 & 13.59 & 4.71 \\
\hline $15-24$ & 12.69 & 13.18 & 7.27 & 13.02 & 13.41 \\
\hline $25-49$ & 38.05 & 32.79 & 32.55 & 29.26 & 48.88 \\
\hline $50-64$ & 18.38 & 19.38 & 29.68 & 22.21 & 18.64 \\
\hline $65+$ & 19.64 & 19.55 & 28.44 & 21.91 & 22.57 \\
\hline $\begin{array}{l}\text { Urban } \\
\text { population }\end{array}$ & 59.95 & 55.73 & 60.92 & 50.84 & 66.49 \\
\hline
\end{tabular}

Source: author's calculation based on the Labour Force Survey.

The age structure of foreign citizens seems to resemble the structure of the domestic population in the 1998-2006 period, according to the sample data. There is a positive difference in the working-age population (25-49) in favour of foreign citizens, which is usually associated with work-rela-

10 See Eurostat (2011) for other issues related to using LFS as a major data source for analysing migration. 
ted migration motives. For example, Božić, Kuzmanović and Barada (2013) have established that the possibility of earning a higher income is one of the most pronounced reasons to decide to move to Croatia. This positive difference for the working-age population is even more pronounced for foreign citizens in the relatively more recent period. There are, however, two issues that deserve attention, which are more pronounced in the first sub-period. The first is related to approximately the same share of foreign citizens aged more than 65 as the domestic population. This seems to be related to the anecdotal evidence of Croatia being the choice of residence country for retirement (Mežnarić, 2008). The second issue is related to the relatively large share (although smaller than in the domestic population) of persons under the age of 24. This might be related to the issue of family reunification. However, since the sample size is relatively small, and not strictly related to the current labour market issues, which are the main focus of this paper, further investigation is left for future research.

We can, however, discuss the origin of immigrants in Croatia. When longer trends are considered, it can certainly be noticed that Croatia has traditionally been a destination country for migrant population from the former Yugoslavian countries. However, the data shows that within the more recent period characterised by increased migration outflows from Croatia, part of those flows was also towards former Yugoslavian countries (Table 2). When these flows are considered, we cannot refrain from mentioning the issue of refugees and displaced persons, related to the war consequences in the 1990s. The data used here precludes drawing specific conclusions on this population, but previous studies indicate that returnees to Croatia are on average older than the local population, actually return to rural areas, have lower educational attainment and are frequently either retired or unemployed (Mesić and Bagić, 2011). Consequently, we cannot expect that this population will actively fill the potential skill shortages demand on the Croatian labour market. 


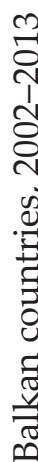

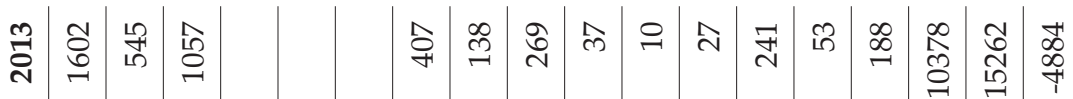

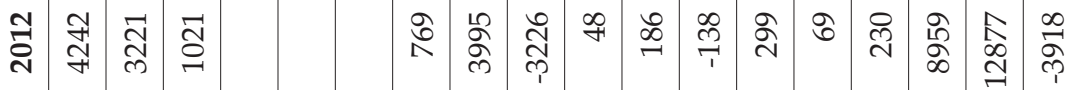

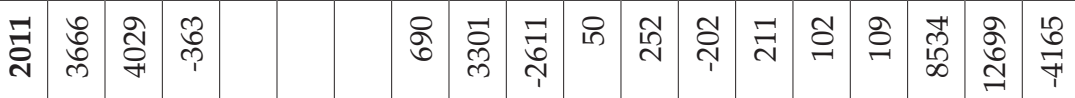

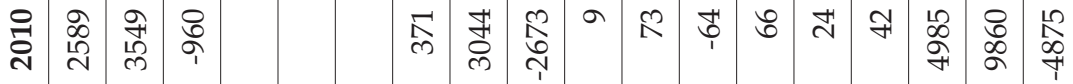

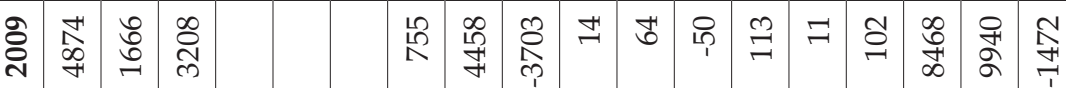

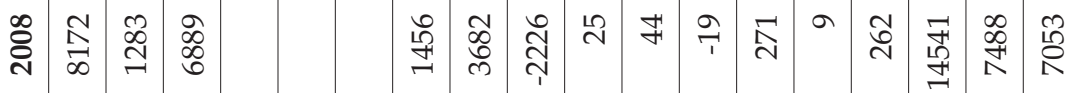

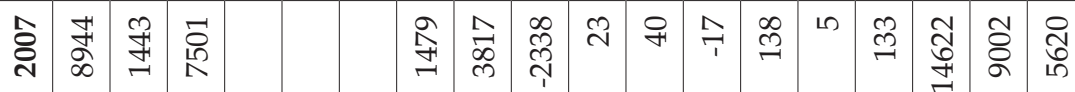

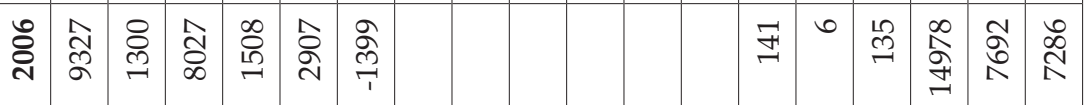

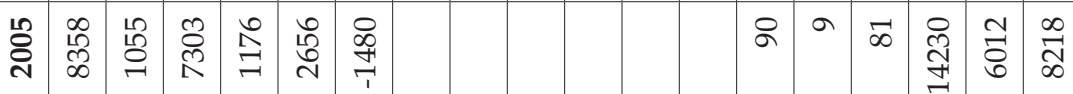

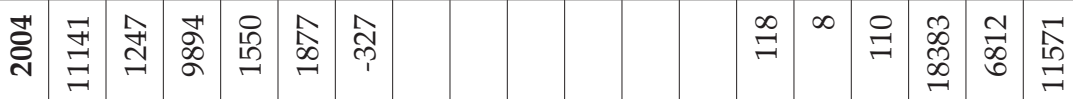

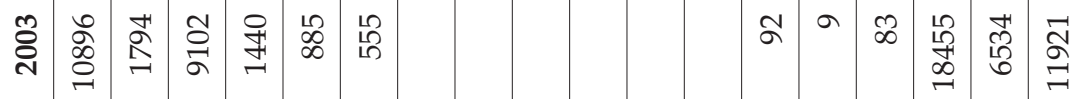

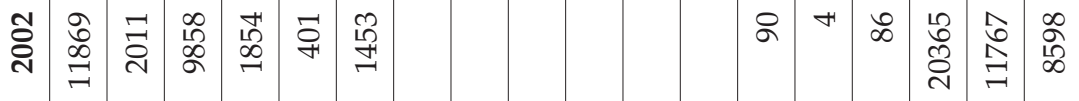

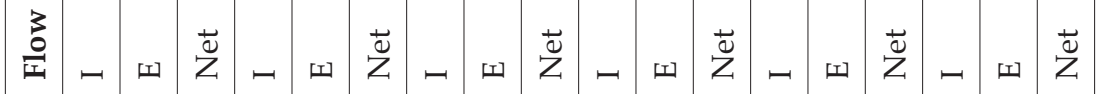

퓽

d

In

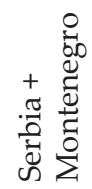

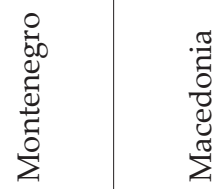

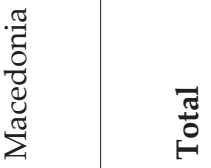

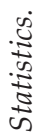

3

$\frac{5}{3}$

స 
As already previously indicated, the LFS sample framework is able to capture only those foreign workers who have permanent residence in Croatia. However, supply on the Croatian labour market has also been under the influence of persons who only temporarily come to Croatia. The major source of the data is the Ministry of the Interior, whose data for the year 2014 reveal the following numbers of temporary stays in Croatia according to major reasons. In addition to the total, we have also chosen to present countries of origin with more than 100 persons temporarily residing in Croatia at the end of 2014, to provide information on origin of immigrants with temporary stay.

Table 3. Main reasons for temporary residence in Croatia on December 31,2014

\begin{tabular}{|c|c|c|c|c|c|c|c|c|c|}
\hline 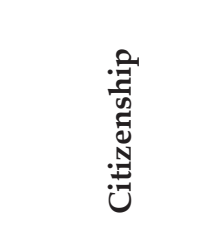 & 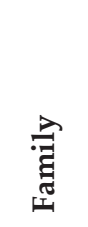 & 产 & 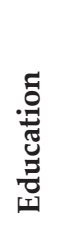 & 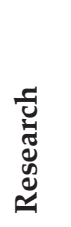 & 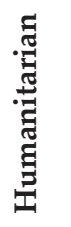 & 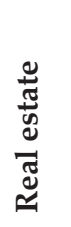 & 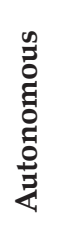 & ذँّ & 胥 \\
\hline $\begin{array}{l}\text { Bosnia and } \\
\text { Herzegovina }\end{array}$ & 542 & 811 & 134 & - & 270 & 27 & 13 & 44 & 1841 \\
\hline Serbia & 125 & 152 & 32 & 1 & 67 & 9 & 1 & 16 & 403 \\
\hline Kosovo & 277 & 56 & 18 & 1 & 30 & 2 & 5 & 7 & 396 \\
\hline China & 202 & 166 & 10 & - & - & - & 2 & 9 & 389 \\
\hline Russia & 150 & 126 & 18 & 1 & 6 & 4 & - & 26 & 331 \\
\hline $\begin{array}{l}\text { FYR } \\
\text { Macedonia }\end{array}$ & 129 & 113 & 35 & 1 & 8 & - & - & 6 & 292 \\
\hline USA & 63 & 111 & 46 & 2 & 4 & 4 & - & 12 & 242 \\
\hline Ukraine & 34 & 61 & 10 & 1 & - & 3 & - & 2 & 111 \\
\hline Total & 1699 & 1905 & 505 & 13 & 403 & 54 & 27 & 177 & 4783 \\
\hline
\end{tabular}

Source: Ministry of the Interior.

The data clearly shows that work-related reasons are the dominant reasons for persons that temporarily stay in Croatia. An additionally important factor is family reunification. Similar to the data on immigration flows, the data on temporary stays also indicates the important role of the former Yugoslavian countries. 
Within the context of the relatively large share of migration flows between Croatia and former Yugoslavian countries, it is important to mention that Croatia is one of the countries participating in the SEE 2020 strategy (Regional Cooperation Council, 2013). One of the goals specified in this document is to promote job creation in the participating countries, with increased regional mobility seen as a contributing factor.

\section{EDUCATION STRUCTURE OF IMMIGRANTS IN CROATIA}

Annual flow data the CBS publishes on migration does not contain any information on their educational attainment. Based on the Ministry of the Interior data, Horvat (2008) shows that almost 50 percent of foreign workers had only high school education and only 10 percent of foreign workers had obtained university education. Similar information is found in the Božić, Kuzmanović and Barada (2013) study. These studies do not compare the educational attainment to the domestic population, which is important in the discussion on the potential skill gap. These comparisons are presented in Table 4.

Table 4. Education structure in percentage, whole population, 1998-2012

\begin{tabular}{lcc|ccc}
\hline & \multicolumn{2}{c|}{ Average 1998-2006 } & \multicolumn{3}{c}{ Average 2006-2012 } \\
\cline { 2 - 6 } & $\begin{array}{l}\text { Foreign } \\
\text { citizens }\end{array}$ & $\begin{array}{c}\text { Croatian } \\
\text { citizens }\end{array}$ & $\begin{array}{c}\text { Foreign- } \\
\text { born }\end{array}$ & Domestic & $\begin{array}{c}\text { Foreign } \\
\text { citizens }\end{array}$ \\
\hline $\begin{array}{l}\text { Primary } \\
\text { and lower } \\
\text { secondary }\end{array}$ & 39.96 & 35.09 & 50.29 & 40.61 & 40.86 \\
\hline $\begin{array}{l}\text { Upper } \\
\text { secondary }\end{array}$ & 34.39 & 38.71 & 37.49 & 36.78 & 40.26 \\
\hline Tertiary & 10.80 & 9.45 & 9.83 & 8.76 & 12.47 \\
\hline
\end{tabular}

Source: author's calculation based on the Labour Force Survey.

The data shows that foreign citizens have a higher share of tertiary education than the domestic population, in particular in the more recent period. Since we have established that in this period the share of the working-age population is higher, it implies that this part of the sample is probably reflecting the work-related migration of highly educated individuals, mostly associated with foreign firms' presence in Croatia. Another pronounced 
characteristic is that it seems that the average education level of the foreignborn population in the more recent period is lower than that of the domestic population. However, the averages for the whole population might be under the strong influence of the return of displaced persons to the waraffected areas. The anecdotal evidence as well as some studies reveal that this is mostly related to the relatively older age cohorts, whose education levels are presumably on average relatively low. ${ }^{11}$ For the labour market, more relevant are those population subgroups that are actually active (i.e. employed or unemployed, but actively seeking a job), since they interact on the labour market with the domestic population. In order to discuss the potential labour market impact of the migrant population, we first restrict the population to those older than 15, active on the labour market. These comparisons are presented in Table 5.

Table 5. Education structure in percentage, active population older than $15^{*}, 1998-2012$

\begin{tabular}{|c|c|c|c|c|c|}
\hline & \multicolumn{2}{|c|}{ Average 1998-2006 } & \multicolumn{3}{|c|}{ Average 2006-2012 } \\
\hline & $\begin{array}{l}\text { Foreign } \\
\text { citizens }\end{array}$ & $\begin{array}{c}\text { Croatian } \\
\text { citizens }\end{array}$ & $\begin{array}{c}\text { Foreign- } \\
\text { born }\end{array}$ & Domestic & $\begin{array}{l}\text { Foreign } \\
\text { citizens }\end{array}$ \\
\hline $\begin{array}{l}\text { Primary } \\
\text { and lower } \\
\text { secondary }\end{array}$ & 31.83 & 25.16 & 36.16 & 31.66 & 31.83 \\
\hline $\begin{array}{l}\text { Upper } \\
\text { secondary }\end{array}$ & 43.61 & 58.05 & 49.27 & 52.70 & 43.61 \\
\hline Tertiary & 14.86 & 15.85 & 14.04 & 15.19 & 14.86 \\
\hline
\end{tabular}

*age was not restricted for the year 1998.

Source: author's calculation based on the Labour Force Survey.

Although the differences are smaller, it seems that certain migrant subgroups have a lower education level than the domestic population. Thus, it seems that Croatia is not, on average, attracting a highly educated labour force (which is the dominant immigrating behaviour of the developed market economies). Rather, it seems that the migrants are filling the lower end of the educational achievement ladder, probably by accepting the jobs deemed as not desirable by the local population. In order to investigate this issue further, we inspect the occupational structure of employed immigrants compared to domestic workers in the next section.

11 This has been shown for the returnee population by Mesić and Bagić (2011). 


\section{EMPLOYMENT CHARACTERISTICS - WAGES AND OCCUPATIONS}

The relative position on the labour market of immigrants in relation to domestic workers could most readily be inspected by their relative earnings. The data for the 2006-2012 period reveals that there are no large differences between the average net wage obtained by foreign-born persons in Croatia and the domestic population. Similar information is also found for the foreign citizens in both analysed periods. However, it has to be emphasized that these are non-adjusted data. Clearly, the wage is, in addition to personal characteristics (such as age, education, as well as more intangible distinctions between individuals), also related to the specific occupation. The LFS specifically provides information on the occupations within the categories defined according to the ISCO classification. Based on the available data from the LFS, occupation in the analysis is defined as the occupation of the main job declared by the employed person, i.e. respondent and classified by the CBS.

Figure 2. Occupation structure of domestic and migrant workers, average 2006-2012

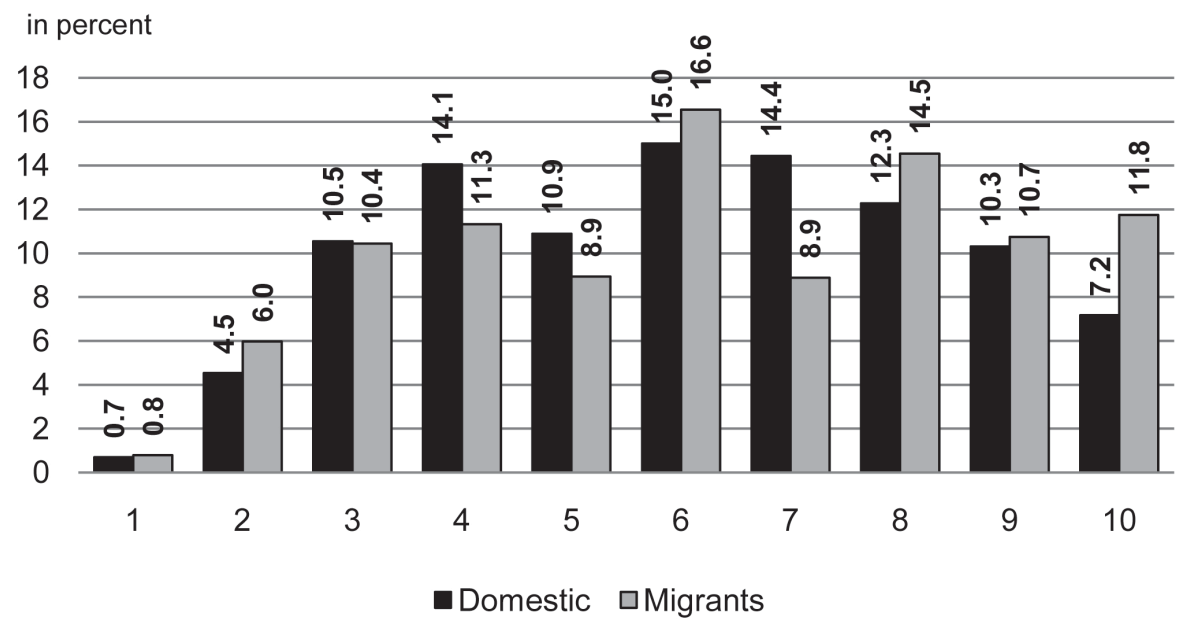

Note: 1 -Armed forces occupations; 2 - Managers; 3 - Professionals; 4 - Technicians and associate professionals; 5 - Clerical support workers; 6 - Service and sales workers; 7 - Skilled agricultural, forestry and fishery workers; 8-Craft and related trades workers; 9 - Plant and machine operators, and assemblers; 10 - Elementary occupations.

Source: author's representation based on the LFS data.

The data in the figure reveals the structure of domestic workers and fo- 
reign-born workers according to the employment in the main job. When the two structures are compared, it seems that domestic workers are more likely to be found among "technicians and associate professionals", "clerical support workers" and "skilled agricultural, forestry and fishery workers". On the other hand, foreign-born persons are more likely to be found working in "elementary occupations", "craft and related trades" or "services and sales". This confirms our previous discussion that the immigrants in Croatia are more likely to find work in low-skill jobs, which has also been confirmed by previous literature. For example, Božić, Kuzmanović and Barada (2013) report the structure of foreign workers with work permits by sector of employment, according to the Ministry of the Interior data in June 2011. This data reveals that the largest proportion is found in construction, followed by ship-building and tourism. These are also the activities that are frequently found in the work permit system introduced in Croatia since 2004.

However, Obadić (2008) argues that the quota system is not matched with the actual demand on the Croatian labour market. She compares the structure of the reported vacancies by the Croatian Employment Service (CES) in the 2004-2007 period with the structure of activities in the quota system and finds a significant mismatch. The question remains whether immigrant workers can have only limited access to certain occupations, due to a potentially vulnerable position on the labour market. For example, MIPEX assessment for Croatia indicates labour market mobility with the indicator 55, which reads "halfway favourable" (Vankova, 2014). This average indicator is further disaggregated into favourable for the integration workers' rights component (value of index 88), slightly favourable access to the labour market (70), halfway favourable access to general support (50) and unfavourable targeted support (13). However, these assessments are based on legislative standards, while the situation on the market might also include other aspects not covered by these considerations. The actual employment data captures those that already have a job, while access to the market might be more difficult.

In terms of increasing matching efficiency, Croatia would certainly benefit if the immigrant workers would be able to fill the gap in the existing labour market demand. However, the evidence so far does not imply that the labour market is clearing in an efficient way in Croatia. This brings us to the question of open unemployment, by immigrant and domestic workers. 


\section{UNEMPLOYMENT INDICATORS OF IMMIGRANT VERSUS DOMESTIC POPULATION}

Croatia is a country with high unemployment rates that has been lingering on throughout the analysed period. In these circumstances, the open question is whether the immigrants perceive Croatia as a desirable country for immigration and also what the outcomes on the labour market are as compared to the local population. The anti-immigration arguments frequently argue that the immigrant population takes jobs from locals ${ }^{12}$ while the affirmative argument relates to the existing gap-filling possibilities that enhance the efficiency of the local labour markets.

In the previous analysis of the position of immigrants on the Croatian labour market, Botrić (2009) uses LFS 2006 data to predict the unemployment status versus employment. The immigrant status is being widely defined - being born outside Croatia, which is consistent with the definition used in the 2006-2012 period in the present paper. The results indicate that immigrant status is a significant positive predictor for unemployment, in both separate analyses of male and female subpopulations. This implies that the immigrants are in a less favourable position on the Croatian labour market than the domestic population. To further elaborate this issue, we present a set of indicators in the following table.

Table 6. Unemployment indicators*

\begin{tabular}{lcc|ccc}
\hline & \multicolumn{2}{c|}{ Average } & 1998-2006 & \multicolumn{3}{c}{ Average 2006-2012 } \\
\cline { 2 - 6 } & $\begin{array}{l}\text { Foreign } \\
\text { citizens }\end{array}$ & Croatian & $\begin{array}{c}\text { Foreign- } \\
\text { born }\end{array}$ & Domestic & $\begin{array}{c}\text { Foreign } \\
\text { citizens }\end{array}$ \\
\hline $\begin{array}{l}\text { Unemployment } \\
\text { rate }\end{array}$ & 44.49 & 24.55 & 25.04 & 19.71 & 36.92 \\
\hline $\begin{array}{l}\text { Share of } \\
\text { unemployed in } \\
\text { sample }\end{array}$ & 20.06 & 11.88 & 12.04 & 9.03 & 18.99 \\
\hline
\end{tabular}

12 Similar arguments have been documented in the Croatian case. For example, ČačićKumpes, Gregurović and Kumpes (2012: 318-319) report that 59.3 percent of respondents believe that foreign workers would additionally burden domestic labour market (responses "agree" and "strongly agree" on a 5-level Likert scale). Exactly the same percentage of respondents believes that if an immigrant has the same qualifications as a domestic worker, employers should prefer the domestic worker. Approximately 30.6 percent of respondents would find it hard to accept that an immigrant holds a superior work position. 


\begin{tabular}{|c|c|c|c|c|c|}
\hline & \multicolumn{2}{|c|}{ Average 1998-2006 } & \multicolumn{3}{|c|}{ Average 2006-2012 } \\
\hline & $\begin{array}{l}\text { Foreign } \\
\text { citizens }\end{array}$ & Croatian & $\begin{array}{c}\text { Foreign- } \\
\text { born }\end{array}$ & Domestic & $\begin{array}{l}\text { Foreign } \\
\text { citizens }\end{array}$ \\
\hline $\begin{array}{l}\text { Share of long-term } \\
\text { unemployed in } \\
\text { unemployment } \\
(>1 \text { year) }\end{array}$ & 80.77 & 75.93 & 69.31 & 67.20 & 83.58 \\
\hline $\begin{array}{l}\text { Share of long-term } \\
\text { unemployed in } \\
\text { unemployment } \\
\text { (>3 year) }\end{array}$ & 73.13 & 63.01 & 49.24 & 45.37 & 74.88 \\
\hline $\begin{array}{l}\text { Share of } \\
\text { unemployed } \\
\text { registered by CES }\end{array}$ & 28.68 & 64.95 & 69.67 & 75.90 & 32.04 \\
\hline $\begin{array}{l}\text { Share of } \\
\text { unemployed with } \\
\text { benefits }\end{array}$ & 5.45 & 11.01 & 12.09 & 15.89 & 6.39 \\
\hline
\end{tabular}

* age was not restricted for the year 1998. CES is the Central Employment Service.

Source: author's calculation based on the Labour Force Survey.

As the data in Table 6 reveals, the share of unemployed persons in the overall sample is much higher for the immigrant than for the domestic population. Consequently, average unemployment rates are higher for immigrants in both analysed subperiods. The duration of unemployment spells is probably longer for the immigrants, since the share of long-term unemployed (both for the persons unemployed longer than one year and longer than three years) in the respective number of unemployed is higher for the migrant than the domestic population. Additionally, it seems that the domestic population is more likely to ask for additional help in finding employment from local institutions (CES) than immigrants.

Cangiano (2012) argues that, in addition to traditional factors that explain the relative vulnerability of immigrants on the local labour markets, there are issues such as non-transferability of skills, discriminatory practices, and also the willingness on the part of migrants to accept the low-qualifications jobs, because they consider them as temporary solutions.

Frequent debate related to migration policies of the European Union countries is the assumed burden the migrant population will place on the existing benefit system (Drinkwater and Robinson, 2011). In Croatia, it seems that the share of unemployed immigrants who are receiving unem- 
ployment benefits is relatively low. This is related to the existing regulations on foreign citizens, ${ }^{13}$ who are entitled to unemployment benefits only if certain conditions are met (previous employment in Croatia for a specific number of months). Although actively stated in public debates as adverse argument for immigration, some studies in other countries actually show that foreigners are less likely to claim benefits (Lisenkova, Merette and Sanchez-Martinez, 2014).

Due to the large number of unemployed and in particular the larger share of the unemployment in the non-domestic sample, it seems appropriate to pose the question of whether migrants have misperceptions about the true nature of the Croatian labour market. One of the simplest ways to capture this is through the concept of the reservation wage. The reservation wage refers to the specific wage the unemployed person would require to accept the job offer. This question has been incorporated in the LFS only since 2006. From this data, it can be seen that the average reservation wage for the whole period was only slightly less than the average wage foreign citizens obtained on the Croatian labour market. There is a similar situation also with the Croatian citizens. Additionally, both subgroups on average declare similar reservation wages. The reservation wage has been analysed in detail in Botrić (2008), where using the LFS for a single year and the broad definition of immigrant status, the result was that immigrants have lower reservation wages, although not statistically significant. Thus, it seems that migrant population did not form unrealistic expectations regarding the wage level on the Croatian labour market.

\section{CONCLUSIONS}

The main goal of this paper has been to analyse the labour market position of immigrant workers in comparison to the domestic labour force. The research question has been inspired by the public debates on unfavourable demographic structure and potential skills gaps in certain economic activities in Croatia. In order to provide additional insights, the Labour Force Survey has been used to reveal the position of immigrants on the Croatian labour market.

Since the LFS sample is not specifically designed to capture the migrant population, the results presented in this paper are able to capture only one segment of the overall ex-post position of migrant workers in Croatia. These

13 Regulated by the Alien Act, which has changed in the past, mostly in order to accommodate EU regulations. 
results confirm that immigrants are predominately employed in traditional sectors perceived in public - occupations that are in general lower skilled. LFS data does not imply that Croatia is able to attract younger and more educated subgroups of population, which would have beneficial impact on the labour market. The data shows that predominately, when the work-age population is considered, the education structure of immigrants resembles domestic structure. Thus, this explorative analysis does not imply that Croatia has been able to attract a more vibrant labour force during the recent period, from which we should expect quantum leaps contributing to the overall economic activity.

The data have also revealed relatively large unemployment problem for immigrants in Croatia. Some indicators imply that the migrant population is facing even more severe problems when trying to find work than the domestic population. How much of that effect should be attributed to the recent economic crisis, remains an open question.

As the administrative data shows, Croatia has recently been faced with increased emigration, which has been enabled with the integration of the labour market into the EU market, but additionally pressured by increased unemployment on the domestic market. During the accession period, studies did not indicate that Croatia would be faced with emigration towards European countries (Švaljek, 2007). More recent contributions imply that Croatia should constantly re-evaluate the competitive position of its labour force with respect to the domestic labour demand and the opportunities that individuals can achieve in the EU market (Bejaković, 2014). In these circumstances, specific skills shortages can occur, as has been already emphasized in the literature with the example of medical workers (Barić and Smolić, 2012).

Having in mind previously stated comments and based on the data revealed, there seems to be a need for a more active migration policy in Croatia (Nejašmić, 2012). The relevant concepts for the new migration policies have been recently emphasized as highly important for the development of society (Božić, 2014). One of the consequences of the prolonged recent economic crisis was additional worsening of the demographic structure in Croatia. Precisely this demographic structure could pose significant constraint for future economic development. In the Croatian case, this is of utmost urgency when adverse demographic structure is considered with the recent out-migration flows of a young and highly educated workforce (Hornstein Tomić and Pleše, 2014). 
Similar to previous research in Croatia, this paper also tries to put emphasis on the important role the immigrant population is expected to play in economic development, already probably in the near future. In order to achieve the potential benefits of an additional labour force, it is extremely important that the skills and qualifications as well as the demographic structure of the immigrants actually fill the existing gap in Croatia. In order to be able to do so, active immigration policy should include all the aspects for successful integration of the immigrant population into Croatian society. This should not only be related to labour market issues, but also to education, housing, social care, health and other issues.

\section{REFERENCES}

Barić, V. and Smolić, Š. (2012). Strategija ljudskih resursa u hrvatskom zdravstvu izazovi ulaska u Europsku uniju, in: G. Družić and I. Družić (eds). Razvojna strategija malog nacionalnog gospodarstva u globaliziranom svijetu. Zagreb: HAZU, 209-226.

Bejaković, P. (2014). Obrazovanje, tržište rada i mobilnost radne snage u Hrvatskoj stanje i problemi, in: V. Puljiz, J. Tica and D. Vidović (eds). Migracije i razvoj Hrvatske - podloga za hrvatsku migracijsku strategiju. Zagreb: HGK, 93-116.

Bernardi F., Garrido, L. and Miyar, M. (2011). The Recent Fast Upsurge of Immigrants in Spain and Their Employment Patterns and Occupational Attainment, International Migration, 49 (1): 148-187, doi: 10.1111/j.1468-2435.2010.00610.x.

Botrić, V. (2008). Odrednice visine uvjetnih nadnica nezaposlenih u Hrvatskoj, Privredna kretanja i ekonomska politika, 18 (117): 29-57.

Botrić, V. (2009). Unemployed and long-term unemployed in Croatia: evidence from Labour Force Survey, Revija za socijalnu politiku, 16 (1): 25-44, doi: 10.3935/rsp. v16i1.807.

Botrić, V. (2012). Regional Differences in Self-employment: evidence from Croatia, Ekonomska istraživanja, 25 (SE1): 243-266.

Božić, S. (2014). Hrvatska migracijska politika: od skice prema strategiji, in: V. Puljiz, J. Tica and D. Vidović (eds). Migracije i razvoj Hrvatske - podloga za hrvatsku migracijsku strategiju. Zagreb: HGK, 285-300.

Božić, S. and Burić, I. (2005). Migracijski potencijal Hrvatske - mikroanalitički aspekti, Migracijske i etničke teme, 21 (1-2): 9-33.

Božić, S., Kuzmanović, B. and Barada, V. (2013). Strani radnici u Hrvatskoj: porijeklo, status, orijentacije, Migracijske i etničke teme, 29 (3): 367-404, doi: 10.11567/met.29.3.3.

Büchel, F. and Frick, J. R. (2005). Immigrants' Economic Performance across Europe - Does Immigration Policy Matter?, Population Research and Policy Review, 24 (2): 175-212. 
Cangiano, A. (2012). Immigration Policy and Migrant Labour Market Outcomes in the European Union: New Evidence from the EU Labour Force Survey. School of Economics, University of the South Pacific, http://www.labmiggov.eu/wp-content/uploads/2012/05/ Cangiano-Lab-Mig-Gov-Final-Report-WP4.pdf (28 March 2014).

Coleman, R. and Rowthorn, D. (2004). The economic effects of immigration into the United Kingdom, Population and Development Review, 30 (4): 579-624, doi: 10.1111/j.1728-4457.2004.00034.x.

Crnković-Pozaić, S. (2008). Buduće potrebe na tržištu rada - možemo li bez imigracije, in: Međunarodna konferencija Useljenička politika u funkciji razvoja hrvatskoga gospodarstva. Zagreb: Hrvatska gospodarska komora, 21-28, http://www2.hgk.hr/upolitika/ zbornik.pdf (15 April 2014).

Čačić-Kumpes, J., Gregurović, S. and Kumpes, J. (2012). Migracija, integracija i stavovi prema migrantima u Hrvatskoj, Revija za sociologiju, 42 (3): 305-336, doi: 10.5613/ rzs.42.3.3.

Dedovic, T. (ed.) (2015). Labour Mobility as a Factor of Development in South-East Europe: Regional Overview. Vienna - Sarajevo: IOM - Regional Cooperation Council Secretariat, http://publications.iom.int/bookstore/free/Labour_Mobility_Factor_ Development_SEE.pdf (30 March 2015.).

Drinkwater, S. and Robinson, C. (2011). Welfare Participation by Immigrants in the UK. Bonn: IZA (IZA Discussion Paper Series, 6144), http://ftp.iza.org/dp6144.pdf (17 May 2014.).

Eurostat (2011). Migrants in Europe: A Statistical Portrait of the First and Second Generation. Luxembourg: Publications Office of the European Union, doi: 10.2785/5318.

Fullin, G. and Reyneri, E. (2011). Low Unemployment and Bad Jobs for New Immigrants in Italy, International Migration, 49 (1): 118-147, doi: 10.1111/j.1468-2435.2009.00594.x.

Horvat, D. (2008). Tko nam dolazi u Hrvatsku, in: Međunarodna konferencija Useljenička politika u funkciji razvoja hrvatskoga gospodarstva. Zagreb: Hrvatska gospodarska komora, 29-34, http://www2.hgk.hr/upolitika/zbornik.pdf (15 April 2014).

Horstein Tomić, C. and Pleše, B. (2014). Skilled mobility as a challange for Croatian diaspora and migration policies, in: V. Varzari et al. (eds.). Skilled Migration and Development Practices: Republic of Moldova and the Countries of South East Europe. Chisinau: École Polytechnique Fédérale de Lausanne - Acad. De Stiinte a Moldovei, 80-95.

Huff, J. O. (1976). A Hierarchical Migration Model of Population Redistribution within a Central Place Hierarchy, Geographical Analysis, 8 (3): 231-254, doi: 10.1111/j.15384632.1986.tb00092.x.

Kogan, I. (2011). New Immigrants - Old Disadvantage Patterns? Labour Market Integration of Recent Immigrants into Germany, International Migration, 49 (1): 91117, 10.1111/j.1468-2435.2010.00609.x.

Lisenkova, K., Merette, M. and Sanchez-Martinez, M. (2014). The Long-Term Impact of Reducing Migration in the UK, National Institute Economic Review, 229 (1): 22-30, doi: 10.1177/002795011422900103.

Markaki, Y. (2014). Public Support for Immigration Restriction in the United Kingdom: Resource Scarcity, Ethnicity or Poor Origins?, National Institute Economic Review, 229 (1): 31-52, doi: 10.1177/002795011422900104. 
Mesić, M. and Bagić, D. (2011). Minority Return to Croatia: Study of an Open Process. Zagreb: UNHCR, http://www.unhcr.hr/images/stories/pdf/minority_return_en.pdf (15 December 2014).

Mežnarić, S. (2008). Migracije u Hrvatskoj: što očekivati, in: Međunarodna konferencija Useljenička politika u funkciji razvoja hrvatskoga gospodarstva. Zagreb: Hrvatska gospodarska komora, 53-64, http://www2.hgk.hr/upolitika/zbornik.pdf (15 April 2014).

Nejašmić, I. (2012). Posljedice budućih demografskih promjena u Hrvatskoj, Acta Geographica Croatica, 38 (1): 1-14.

Nestić, D., Rubil, I., Stubbs, P. and Tomić, I. (2013). The Employment and Social Situation in Croatia. DG for Internal Policies, Policy Department A: Economic and Scientific Policy, http://www.europarl.europa.eu/RegData/etudes/note/join/2013/507478/ IPOL-EMPL_NT(2013)507478_EN.pdf (19 March 2014).

Obadić, A. (2008). Ocjena stanja hrvatskog tržišta rada i njegova mobilnost, in: Međunarodna konferencija Useljenička politika u funkciji razvoja hrvatskoga gospodarstva. Zagreb: Hrvatska gospodarska komora, 97-110, http://www2.hgk.hr/upolitika/ zbornik.pdf (15 April 2014).

Plane, D. A., Henrie, C. J. and Perry, M. J. (2005). Migration up and down the urban hierarchy and across the life course, Proceedings of the National Academy of Sciences of the United States of America, 102 (43): 15313-15318, doi: 10.1073/pnas.0507312102.

Regional Cooperation Council (2013). South East Europe 2020: Jobs and Prosperity in a European Perspective, http://www.rcc.int/files/user/docs/reports/SEE2020-Strategy. pdf (17 April 2014).

Saleheen, J. and Shadforth, C. (2006). The Economic Characteristics of Immigrants and the Impact on Supply, Quarterly Bulletin, Bank of England, 4: 374-385, http://www. bankofengland.co.uk/publications/Documents/quarterlybulletin/qb060401.pdf (15 April 2014).

Sandström, S. (2002). The Consequences of within Households Unit Non-Response in Income Distribution Analysis, (CHINTEX Working Paper, 2), https://www.destatis. de/DE/Methoden/Methodenpapiere/Chintex/ResearchResults/Downloads/ WorkingPaper2.pdf?_blob=publicationFile (10 September 2013).

Švaljek, S. (ur.) (2007). Pristupanje Europskoj uniji: očekivani ekonomski učinci. Zagreb: EIZ. Vankova, Z. (2014). Hrvatska: indeks razvijenosti politika integracije migranata (MIPEX) / Croatia: A MIPEX assessment. Zagreb: Institut za migracije i narodnosti, http:// www.imin.hr/c/document_library/get_file?uuid=59d7e46c-5152-4a8d-ad14a296e468d6ca\&groupId=10156 (13 May 2014).

\section{SOURCES}

Migracija stanovništva Republike Hrvatske / Migration of Population of Republic of Croatia, 1998 - 2012, Priopćenje / First Release 7.1.2, Državni zavod za statistiku, Zagreb.

Narodne novine, 2003 - 2013 (NN 194/2003, NN 57/2004, NN 185/2004, NN 153/2005, NN 30/2007, NN 106/2008, NN 150/2009, NN 88/2011, NN 25/2012, NN 144/2012, NN 151/2013). 


\section{Karakteristike doseljenih osoba i hrvatsko tržište rada: eksplorativno istraživanje}

\section{Valerija Botrić}

\section{SAŽETAK}

Posljedice doseljavanja na tržište rada zanimljive su s različitih aspekata, ne samo kao istraživačko pitanje već i naročito zbog potrebe oblikovanja adekvatnih političkih mjera. S istraživačkog stajališta zanimljiva su pitanja nalaze li se doseljene osobe u relativno lošijoj poziciji na tržištu rada, u kojem su segmentu tržišta rada aktivne i je li njihov doprinos ukupnome ekonomskom razvoju zemlje domaćina pozitivan. Oslanjajući se većinom na podatke Ankete o radnoj snazi za razdoblje 1998. - 2012., ovo istraživanje nastoji prikazati poziciju doseljenih osoba u Hrvatskoj. Nekoliko pokazatelja usporedno se analizira za doseljenu i domaću populaciju - starost, stupanj obrazovanja, struktura po zanimanjima i nezaposlenost. Podaci pokazuju da doseljene osobe u Hrvatskoj ne pripadaju mladoj i obrazovnoj populaciji - te karakteristike povezuju se u većoj mjeri s emigracijskim profilima - već su sličnije populaciji zemlje u koju su se doselili.

KLJUČNE RIJEČI: doseljene osobe, Hrvatska, tržište rada, Anketa o radnoj snazi 